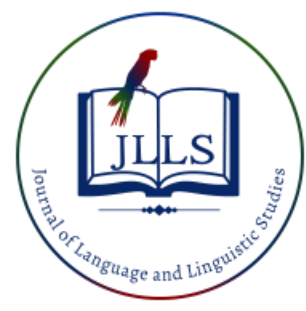

Available online at www.jlls.org

JOURNAL OF LANGUAGE AND LINGUISTIC STUDIES

ISSN: 1305-578X

Journal of Language and Linguistic Studies, 17(3), 1427-1439; 2021

\title{
The pragmatics of bullying in selected political speeches of Donald trump
}

\author{
Fareed Hameed Al-Hindawi a iD, Mariam D. Saffah ${ }^{\text {b }}$ iD, Akram Nadhim Raheem ${ }^{\text {c1 }}$ iD \\ ${ }^{a, b, c}$ College of Education, Islamic University, Najaf
}

\section{APA Citation:}

Hindawi, F. H. A, Saffah, M. D, Raheem, A.N. (2021). The pragmatics of bullying in selected political speeches of Donald trump. Journal of Language and Linguistic Studies, 17(3), 1427-1439. Doi: 10.52462/jlls.103

Submission Date:22/05/2021

Acceptance Date:20/08/2021

\begin{abstract}
It is suggested that bullying refers to an interpersonal interaction which is marked by an aggressive behaviour carried out by one party against another. It is characterized by imbalance of power between the persons concerned. Bullying is ubiquitous in political arena where political leaders and candidates frequently resort to utilizing different strategies of bullying in order to attack their rivals and create a positive image for themselves which enables them to achieve their goals. Pragmatically, this issue has not been given its due attention. Thus, this study constitutes a try at bridging this gap in the literature via answering the questions below: What are the functions of bullying produced in the data under study? What are the types of bullying resorted to by Donald Trump? What are the pragmatic structure of bullying produced in the data under scrutiny? And what are the pragmatic strategies utilized by Donald Trump to bully his victims?
\end{abstract}

Key Words: Bullying; definitions, types; functions; pragmatics; political speeches; bullying strategies.

\section{Introduction}

Bullying requires a relationship with an imbalance of power which occurs when someone is exposed repeatedly to aggressive actions. These actions are possible to be performed verbally, for instance, by threatening, taunting, teasing, and calling names. Besides, it is possible to perform them physically by hitting, pushing, or restraining someone (Olweus, 1993: 14).

While not denying the importance of other contexts for bullying, political bullying is of a particular interest where political leaders and candidates frequently resort to employing numerous bullying tactics to cast doubt on their political opponents' abilities and gain the support of the public.

\subsection{Definitions}

According to Merriam Webster Online Dictionary, to bully means to treat someone in cruel, insulting, threatening, or an aggressive manner. Similarly, Smith and Sharp (1994: 2) mentions that bullying refers to a systematic abuse of power. The degree of what constitutes abuse will rely on the social and cultural contexts. When the abuse is repeated and deliberate, bullying constitutes a good term to describe it.

\footnotetext{
${ }^{1}$ Corresponding author.

E-mail address: akram.akram.salami76@gmail.com
} 
As for this study, bullying is defined as a subtype of incivility which is marked by power imbalance between the parties involved and a repeated verbal aggression produced by a perpetrator against a victim to achieve a spectrum of interpersonal functions.

\subsection{Incivility and Bullying}

Coe and Rains (2014) who study incivility as manifested in public discussions, believe that defining incivility is not an easy task, this is due to the fact that what is considered by one person as uncivil might be proper conduct to another. However, it can be taken as characteristics of discussion that express a rude tone towards the discussion forum, its participants or its topics.

As regards the relationship between incivility and bullying, it is assumed that incivility differs from bullying in the sense that bullying involves negative words or actions that spiral over a span of time to socially eliminate a certain person or group. Additionally, the latter demands power imbalance between the bully and the victim accompanied by an obvious intention to hurt another. (Chen, 2017.: 6)

\subsection{Pragmatics, Context, and Intention}

Since the current study investigates bullying from a pragmatic point of view, it is necessary to focus on the related notions of context and intention.

Mey (2001: 6) asserts that pragmatics perceives language as greatly influenced by the context in which it appears. That is, it is interested in looking from the underlying systematic patterns employed by the language users and it looks at the intention beneath the words.

Concerning the role of intent in bullying, Einarsen et al., (2003: 12) suggest that this depends on both whether the perceived negative act is intended in the first place and the likely harmful outcome of the conduct.

\section{Donald Trump's Political Discourse}

According to York (2013: 109), many scholars suggest that American politics is starting an era of highlighted incivility, represented by free exhibitions of disrespectful political rhetoric and behaviour. Nithyanand et al. (2017: 1) mention that several factors including the rising popularity of Donald Trump contribute to the declining quality of American political discourse. Similarly, Lakoff (2017:2) states that Trump desperately wants to be a macho man. Thus, he echoes sentences fragments, reuses the very words and phrases, and boasts.

\section{The Model: Introduction}

This section will concentrate on developing a pragmatic model to be used for analyzing the data of the present paper.

\subsection{Incivility}

In their study of workplace incivility, Andersson and Pearson (1999: 454) draw on the notion of conflict escalation processes. They depict incivility as a sort of social interaction illustrating how incivility can spiral and probably escalate into increasingly intense and hostile workplace behaviours.

Similar to both concepts of conflict and incivility, bullying is a process that can potentially escalate beginning with more subtle and low-level aggression and moving to more direct and intense aggressive behaviours (Einarsen, 1999: 20) 


\subsection{Types of Bullying}

For Gladden et al. (2014: 7) four kinds of bullying can be recognized. They are physical, verbal, relational and damage to property bullying. Each type assumes different forms and fulfills different spectrum of functions.

\subsection{Bullying Functions}

According to Swearer and Hymel (2015: 344), bullying denotes an exceptional but intricate form of interactive aggression which assumes numerous forms and fulfills various functions. One of the most important functions of bullying is the need to control. The second function is to get more power. The aim is to make bullies appear superior to their victims.

Getting emotional response on the part of a target or an audience represents the third function of bullying. For example, in the 2016 election both candidates engaged in bullying conduct where the Democratic nominee Hillary Clinton named people who support the Republican nominee "deplorable", and said they were "irredeemable". In return, Donald Trump called her "nasty woman" and referred to her as "crooked Hillary." (Gordon, 2019:1-2).

Furthermore, it is worth mentioning that bullies sometimes utilize bullying in order to avoid taking responsibility. (Oade, 2009: 32).

\subsection{The Eclectic Model}

As regards this study, the model of analysis is based on the ideas and concepts derived from what has already been tackled. It is also worth mentioning that the situations under scrutiny are regarded as bullying according to the availability of the three criteria of intentional aggression, repetition and power imbalance. That is, if one or more of these is available, the situation is to be taken as bullying.

Due to the fact that bullying is an interpersonal process, it extends over three stages: initiation, escalation and termination. The terminology is borrowed from Leung's (2002) model of conflictive talk. Hence, since bullying occurs in conflictive discourse, it passes through stages.

\subsubsection{The initiation Stage}

Van Eemeren and Houtlosser (2002: 135) believe that it is feasible to mingle rhetorical intuitions with a dialectical structure of argumentation via the concept of strategic maneuvering. Hence, three inseparable aspects of strategic maneuvering have been identified: topical potential, audience demand, and presentational devices.

As for this study, only the two poles of topical potential and audience adaptation will be adopted in analyzing data. The former is achieved through speech acts strategies while the latter is fulfilled via pragma-rhetorical strategies.

Speech act strategies

These include the following speech acts: Telling, claiming, and stating.

\section{Pragma-Rhetorical Strategies}

These include argumentative appeals and pragma-rhetorical tropes

\subsubsection{The escalation stage}

This stage is marked by the use of various structural components. The first of these are macro strategies. 


\section{Macro Strategies}

According to Gordon (2019: 2), politicians frequently resort to using the following strategies to bully their opponents politically. These include: Blame-shifting, Rumour Spreading, and Reputation bashing

\section{Micro Strategies}

The macro strategies outlined above can be achieved via the following micro strategies.

\section{Speech Act Strategies}

Speech acts resorted by the speaker to bully his target include accusation, insulting, teasing, criticizing, stating and requesting

\section{Impoliteness Strategies}

Culpeper (2011: 257) suggests that bullying belongs to what is referred to as coercive impoliteness. Coercive impoliteness "is impoliteness that seeks a realignment of values between the producer and the target such that the former benefits or has his current benefits reinforced or protected."

As for the present study, the researchers analyze Trump's political discourse which contain bullies by using the five impoliteness strategies proposed by Culpeper's (1996: 355-7). These include: bold on record impoliteness, positive impoliteness, negative impoliteness, sarcasm or mock impoliteness, and withhold politeness.

\section{Conversational Maxims breaches}

According to Grice (1975: 49) it is assumed that "every language user will follow these maxims and expect his partner to do so. However, if an interlocutor can and in a position to follow a specific maxim, but intentionally and bluntly infringes it, a conversational implicature can be generated."

\subsubsection{The termination stage}

As regards the termination stage, speakers employ solitary structural components in order to terminate the interactive processes of bullying. They resort to the speech acts of threat, warning, prohibition, stating and telling.

The model of bullying developed in this section is illustrated in Figure (1) below:

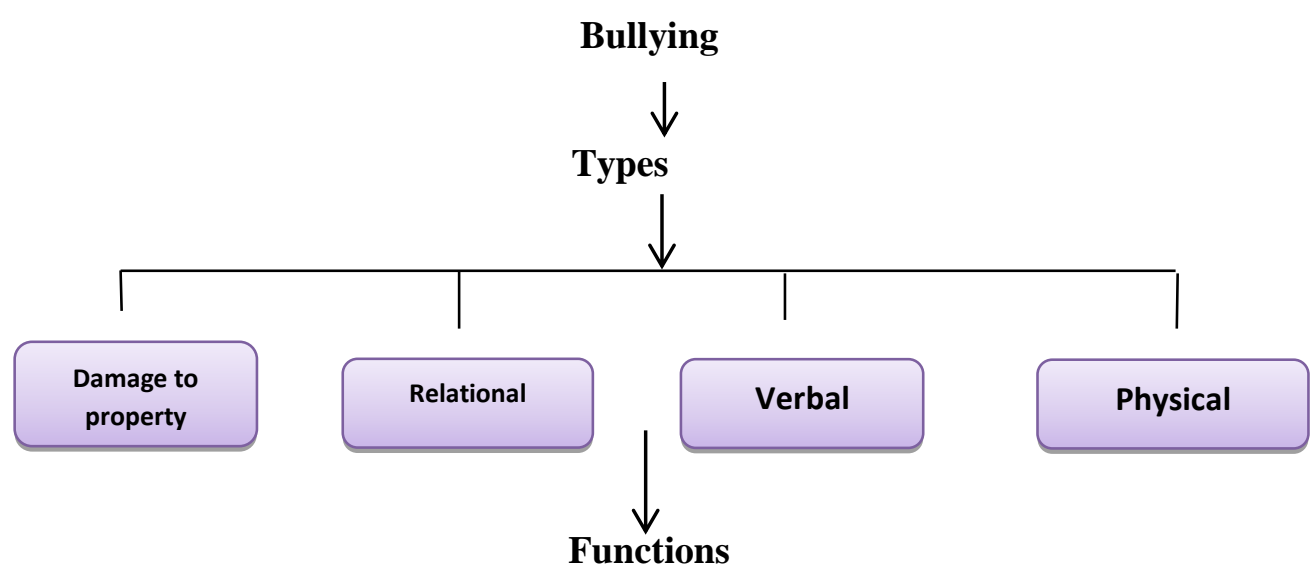




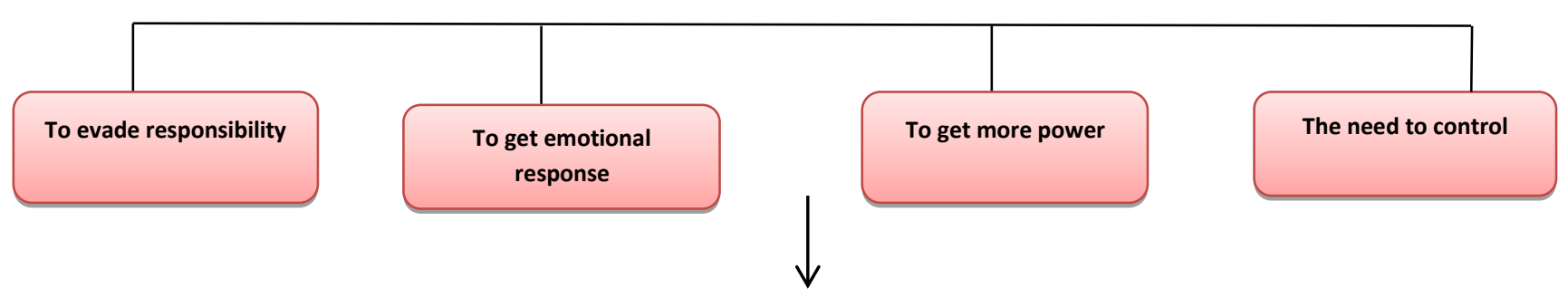

\section{Pragmatic Structure}
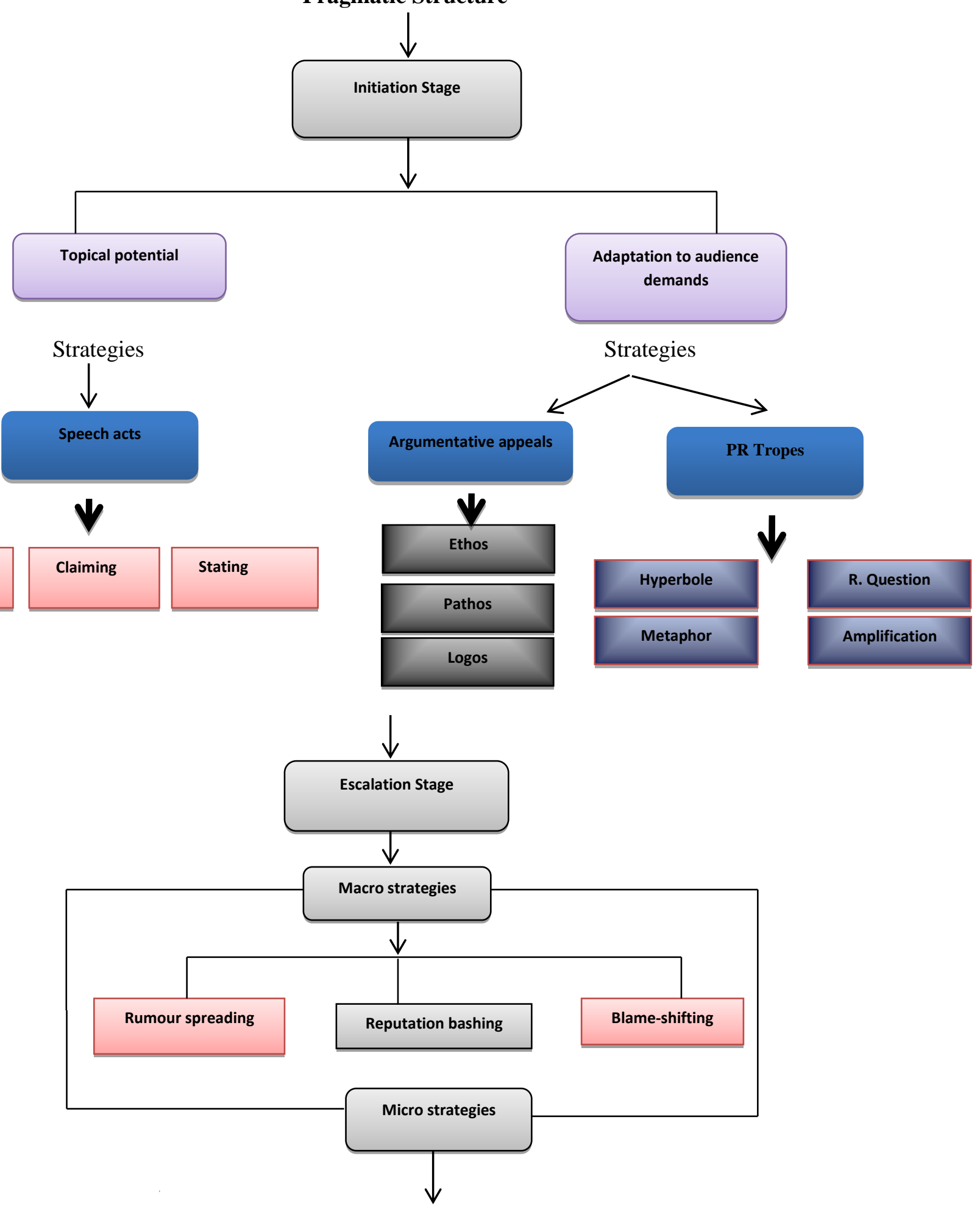
conversational maxims breaches
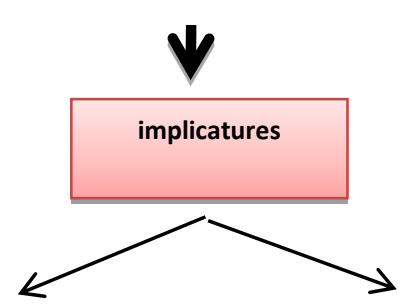

conventional conversational
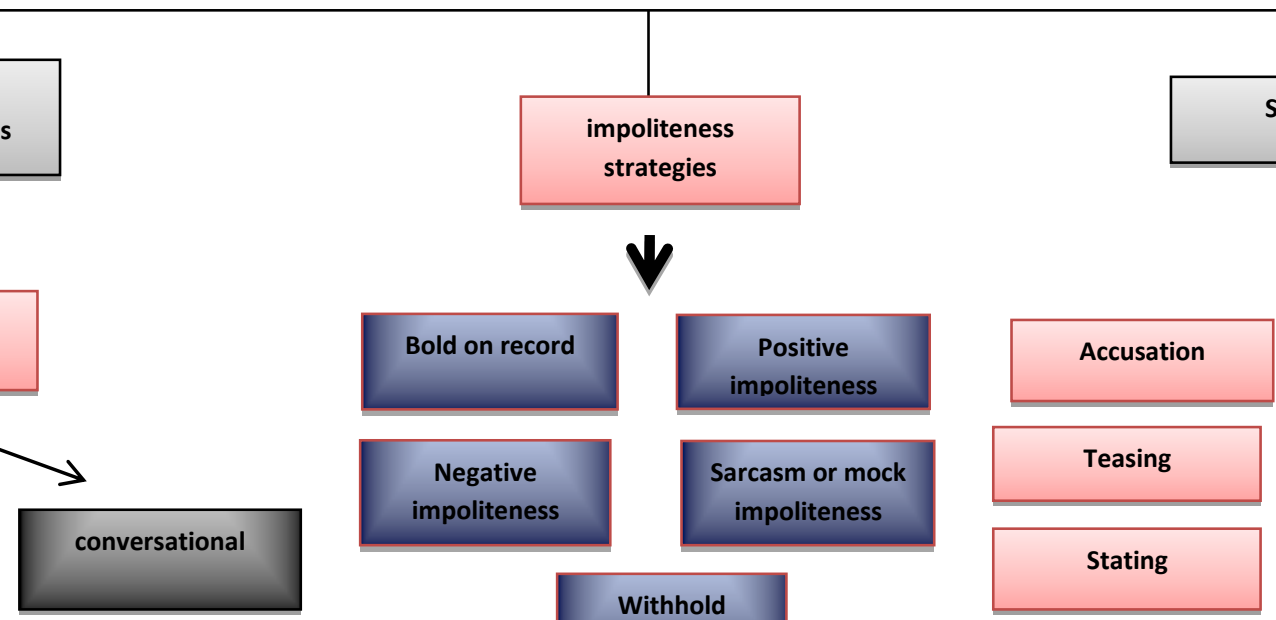

Teasing

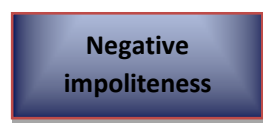

Sarcasm or mock

impoliteness
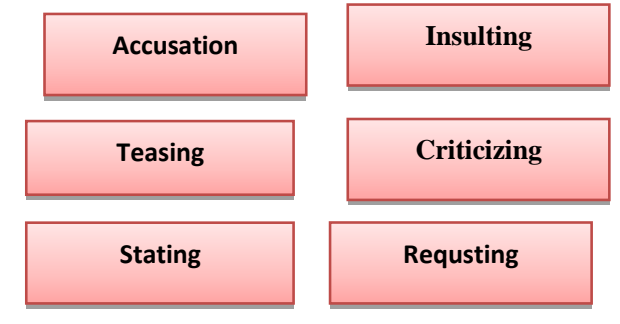

Criticizing

Requsting

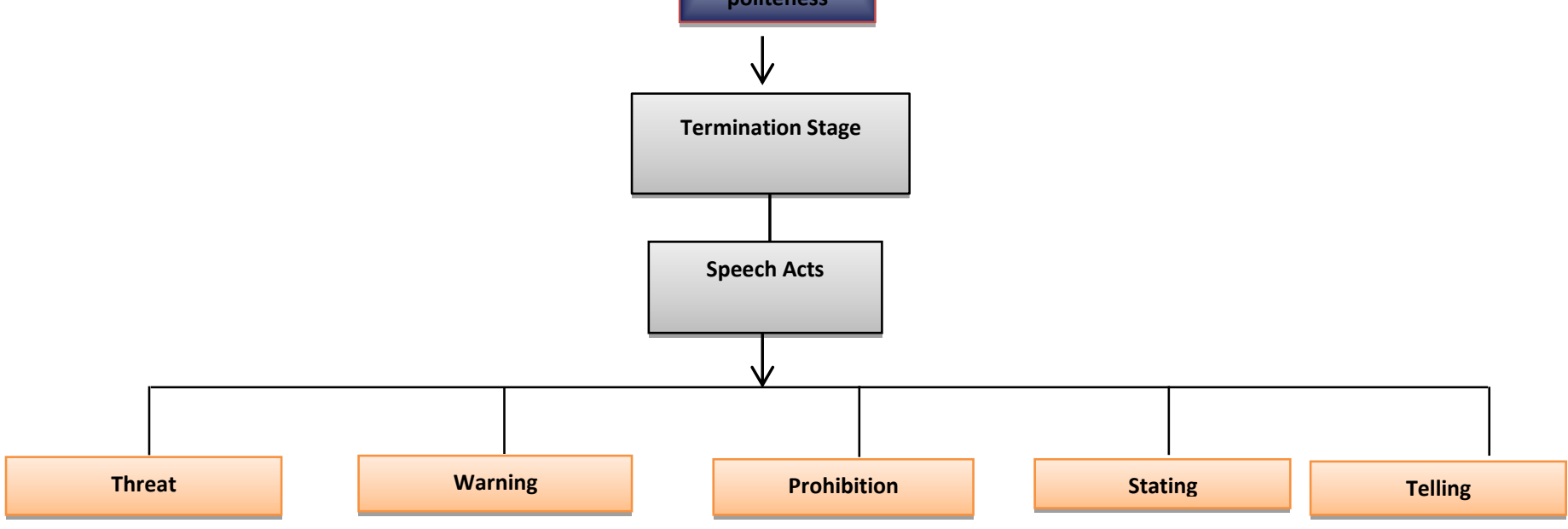

Figure 1. The Eclectic Model for the Analysis of Bullying

\subsection{Data and Analysis: Introduction}

As for this study, the data are collected from four political speeches produced by Donald Trump. Nine different situations are quoted in order to be analyzed in accordance with the eclectic model developed by this study. Three of them have been chosen as illustrative examples representing the analysis of the remaining situations.

\subsection{Data Description}

\subsubsection{Political Speeches}

According to Atkinson (1984: 1), the faculty of being able to talk efficiently in public constitutes one of the most antique and forceful arms that proficient politicians possess. In fact, leaders of nations, political parties and mass movements conventionally perceived as the most persuading spokesmen for their cause.

\subsection{Data Analysis}

\subsubsection{Model of Analysis}


The eclectic model developed in the previous section is used for analyzing the bullying situations in the political speeches under study (cf 3.5).

\subsubsection{Pragmatic Analysis}

This section is dedicated to the pragmatic analysis of bullying. It will start with analyzing Trump's political speeches pragmatically and according to the developed model.

\section{Situation 1 :}

"When Mexico sends it people, they're not sending the best. They're not sending you, they're sending people that have lots of problems and they're bringing those problems. They're bringing drugs, they're bringing crime. They're rapists and some, I assume, are good people, but I speak to border guards and they're telling us what we're getting. With Mexico being one of the highest crime Nations in the world, we must have THE WALL" Trump (2015)

\section{Criteria}

Two criteria are clearly manifested in the situation above. Trump employs them to serve his intention to bully his opponents.

1. An aggressive behaviour: During his campaign, Trump informs his supporters his intention to construct the boarder wall. When he takes office, Trump signs an executive order to build the wall that separates the United States from Mexico. Consequently, he is waging an economic war against Mexico

2. Imbalance of power: The boarder wall is constructed in pursuit of controlling illegal immigration from Mexico. The speaker is more powerful than undocumented Mexican immigrants.

\section{Types}

Trump utilizes verbal bullying. He uses offensive language to belittle and insult Mexican immigrants: "They're bringing drugs, they're bringing crime." "They're rapists".

\section{Pragmatic Structure}

\section{Initiation stage}

\section{Topical potential strategies}

In this situation, Trump initiates his speech via selecting a topic pertaining to what is considered to be reasonable. This is achieved through a speech act strategy. The speaker issues a statement which serves to belittle Mexican immigrants portraying them as much worse individuals than their American counterparts: "When Mexico sends it people, they're not sending the best. They're not sending you"

\section{Adaptation to audience demands strategies}

For optimal outcome, Trump tries to adapt to audience demands by means of argumentative appeals. First, the speaker is portrayed as a moral arbitrator by characterizing illegal immigrants as being bad individuals. This assists to create a positive ethos. Concerning pathos, Trump appeals to audience's desires to get rid of illegal immigration since many working class American regard Mexican immigrants to be responsible for their numerous economic problems. With regard to logos, this is also manifested in Trump's utterance

\section{Escalation stage}




\section{Macro strategies}

The current stage is marked by employing a macro strategy of blame-shifting. Here, Trump blames Mexican undocumented immigrants for all his nation's economic problems. Additionally, the strategy of reputation bashing also occurs in this stage when Trump attempts to damage the opponents' reputation by describing them as rapists.

\section{Micro strategies}

The macro strategies above are attained via speech act, impoliteness strategies and generalized scalar impilcature. The former is realized by an offensive speech act of insult. Trump is inclined to belittle Mexican immigrants via characterizing them as being drug smugglers, criminal and rapists.

"They're sending people that have lots of problems and they're bringing those problems. They're bringing drugs, they're bringing crime. They're rapists."

Moreover, the speaker employs negative impoliteness strategies. First, he belittles Mexican immigrants when he says "they're not sending the best" Besides, Trump overtly associates them with negative aspects, they are ones who bring drugs, crimes and they are rapists.

Furthermore, this stage also contains generalized scalar implicatures, "some, I assume, are good people." By choosing some, Trump generates the impicature not all

\section{Termination stage}

\section{Speech act strategies}

The process of bullying is terminated with a statement: "With Mexico being one of the highest crime Nations in the world, we must have THE WALL." Trump believes that Mexico is one of the world highest crime nations. This speech act serves to mobilize the audience against illegal immigration from Mexico.

\section{Situation 2 :}

"It's not unconstitutional keeping people out, frankly, and until we get a hold of what's going on. And then if you look at Franklin Roosevelt, a respected president, highly respected Take a look at presidential proclamations back a long time ago what he was doing with Germans, Italians, and Japanese, because he had to do it. Because look, we are at war with radical Islam."

"We're having problems with the Muslims, and we're having problems with Muslims coming into the country... You need surveillance. You have to deal with the mosques, whether you like it or not.

These attacks are done by Swedish people" Trump (2017)

\section{Criteria}

Three criteria of bullying are obviously manifested in the current situation. They are collectively employed by the speaker to bully the Muslims.

1. An aggressive behaviour: Trump signs an executive order banning citizens from seven Muslim countries (Iraq, Syria, Iran, Libya, Somalia, Sudan and Yemen) for a period of 90 days.

2. Repeated behaviour: Six months later, Trump signs another executive order that substitutes the first one issued on January $27^{\text {th }}$. The order still constrains the entry of six Muslim countries removing Iraq from the list of banned countries. 
3. Imbalance of power: As president of the world's most powerful country, Trump has more power than the governments or the citizens of the banned countries.

\section{Types:}

The speaker resorts to a verbal version of bullying via directly attacking Muslims refugees to limit their entry into the United State

\section{Pragmatic Structure}

\section{Initiation stage}

\section{Topical potential strategies}

In this instance, Trump chooses a topic which is reasonable and logically persuasive to the audience. This is realized by a speech act strategy of a statement. Trump believes that it is quite constitutional to limit the number of Muslims refugees admitted to the United States him.

"It's not unconstitutional keeping people out, frankly, and until we get a hold of what's going on."

Another topical potential strategy assumes the form of a speech act of request. Trump asks audience to consider the experiment of president Franklin Roosevelt during the second world war when he constrained the entry of Germans, Italians and Japanese to the United States.

"And then if you look at Franklin Roosevelt, a respected president, highly respected. Take a look at presidential proclamations back a long time ago what he was doing with Germans, Italians, and Japanese, because he had to do it. Because look, we are at war with radical Islam."

\section{Adaptation To audience demands strategies}

In order to comply with audience needs and preferences, Trump employs argumentative appeals. Concerning ethos, an appeal to authority assumes the form of reference to president Franklin Roosevelt. Additionally, another appeal to ethos pertains to similitude which stimulates similarities between Trump and the audience reflected in the use of the pronoun we. As for pathos, the speaker attempts to provoke the feelings of audience by showing concern about a subject with global impact. He refers to the spreading of radical version of Islam. Regarding logos, Trump tries to promote the thesis that since the United States is at war with radical Muslims, a temporary shutdown of Muslim refugees is necessary.

\section{Escalation stage}

\section{Macro strategies}

The present stage is distinguished by the utilization of the strategy of blame-shifting. Trump blames Muslim refugees for the prevailing of terrorist attacks launched against targets in the United States. Another strategy of reputation bashing also used. Trump tries to violate Muslims' reputation when he characterizes them as bad and evil.

\section{Micro strategies}

In the situation above, two macro strategies are resorted to. First, Trump employs a speech act of statement: "We're having problems with the Muslims, and we're having problems with Muslims 
coming into the country." This serves to strengthen the previous speech act and to gain the support of audience to Trump's executive order.

A negative impoliteness strategy is utilized by Trump. Trump ubiquitously associates Muslims with evil.

\section{Termination stage}

\section{Speech act strategies}

It can be seen that bullying is ended as it begins with a statement: "You have to deal with the mosques, whether you like it or not. These attacks are not done by Swedish people." This assertion functions to enhance Trump's belief that Muslims are responsible for terrorist attacks.

\section{Situation : $^{2}$}

"Big business, elite media and major donors are lining up behind the campaign of my opponent because they know she will keep our rigged system in place. They are throwing money at her because they have total control over everything she does. She is their puppet, and they pull the strings. That is why Hillary Clinton's message is that things will never change. My message is that things have to change-and they have to change right now" Trump (2016).

\section{Criteria:}

Two criteria are utilized in the present situation, Trump employs them to bully his opponent:

1. An aggressive behaviour: Trump attacks Hillary Clinton promising to send her to prison as soon as he wins election in consequence of her emails deletion.

2. Repeated behaviour: Trump repeatedly threatens to make Hillary Clinton pay for her mistakes and wrong polices.

\section{Types:}

As before, the speaker uses verbal bullying in the situation above. He resorts to offensive language to belittle and insult his opponent.

\section{Pragmatic structure}

\section{Initiation stage}

\section{Topical potential strategies}

In this stage, Trump utilizes a speech act strategy in order to achieve topical potential. He produces an assertion stating that several powerful groups support the campaign of Hillary Clinton financially because she will keep things the way that serve the interests of such groups who control her actions.

"Big business, elite media and major donors are lining up behind the campaign of my opponent because they know she will keep our rigged system in place."

\section{Adaptation to audience demands strategies}

To increase rhetorical effectiveness on audience, the speaker employs a metaphor. This is shown in: "They are throwing money at her." Hence, the extent of Hillary Clinton's corruption and manipulation is stressed to enhance an argument in favour of condemning her. 
Related to argumentative appeals Trump is portrayed as a man of principles who rejects corruption, bribe and manipulation. This assists to produce a positive ethos. An appeal to pathos occurs when Trump shows a concern about audience's desires to have an efficient leader. As regards logos, the speaker tries to promote the thesis that Hillary Clinton is to blame for her mistakes and wrong policies.

\section{Escalation Stage}

\section{Macro strategies}

Trump employs a macro strategy of reputation bashing in the situation above. He intends to violate the reputation of his opponent by discussing her character in public in order to disparage her in the eyes of audience.

\section{Micro strategies}

The escalation stage is marked the occurrence of two micro strategies: speech act and impoliteness strategies. As for the former, Trump produces an offensive speech act of insult in order to express his disapproval of his opponent's acts.

"She is their puppet, and they pull the strings"

Additionally, use is made of a negative impoliteness strategy. The speaker belittles Hillary Clinton describing her as a puppet whose actions are fully controlled by powerful groups.

\section{Termination stage}

\section{Speech act strategies}

As for this situation, bullying is concluded with an implicit threat. Trump implicitly threatens to take action in order to amend the current situation which is caused by his opponent's wrong polices, "That is why Hillary Clinton's message is that things will never change. My message is that things have to change - and they have to change right now."

\section{Conclusions}

The following conclusions can be introduced:

1. Bullying is an interactive process comprising three stages: initiation, escalation and termination. Each is marked by the use of particular pragmatic elements that form the pragmatic structure of bullying.

2. The findings of the study show that the three criteria of bullying outlined in the present study are prevailing in Trump's political speeches under study.

3. Concerning types, the analysis of data demonstrates that Trump resorts to verbal and relational bullying while physical and damage to property have not occurred in the data under scrutiny. Moreover, verbal bullying dominates the data.

4. It has also been revealed that bullying strategies are utilized all over the pragmatic structure of bullying. They include: speech acts, argumentative appeals, pragma-rhetorical tropes, macro and micro strategies. Among these, speech acts are used along the three stages of bullying situations produced by Trump. However, some speech acts such as that of teasing and prohibition have not been resorted to.

5. It is worth mentioning that most bullying instances scrutinized in the present work are performed by Trump in contexts where the speaker wishes to gain more power in order to appear superior to his 
opponents, or in cases where the speaker wants to avoid responsibility in relation to certain crises, polices or decisions.

6. This study shows that Donald Trump has succeeded in bullying his rivals by making an extensive use of a continuum of bullying strategies. By characterizing his opponents in terms of goodness and evilness, he ridicules them publically and simultaneously proclaims himself as the perfect leader for the United States.

\section{References}

Andersson, L., \& Pearson, C. (1999). Tit for Tat? The Spiraling Effect of Incivility in the Workplace. Academy of Management Review, 24(3), 452-71.

Atkinson, M. (1984). Our Masters' Voices. London: Methuen and Co.

Chen, G. M. (2017). Online Incivility and Public Debate. Austin: Palgrave.

Coe, K., \& Rains, S. (2014). Online and Uncivil? Patterns and Determinants of Incivility in Newspaper Website Comments. Journal of Communication, 64, 658-679.

Culpeper, J. (1996). Towards an anatomy of impoliteness. Journal of Pragmatics, 25, 349-67.

Culpeper, J. (1996). Impoliteness: Using Language to Cause Offence. Cambridge: Cambridge University Press.

Einarsen, S. (1999). The Nature and Causes of Bullying. International Journal of Manpower, 20, 1627.

Einarsen, S., Hoel, H., Zapf, D. and Cooper, C. (2003). The Concept of Bullying at Work: The European Tradition. In Einarsen, S., Hoel, H., Zapf, D. \& Cooper, C. (Eds.). Bullying and Emotional Abuse in the Workplace. London: Taylor and Francis Group.

Gladden, R., Vivolo-Kantor, A., Hamburger, M. and Lumpkin, C. (2014). Bullying Surveillance among Youths: Unifor Definitions for Public Health and Recommended Data Elements. Atlanta: National Center for Injury Prevention and Control.

Gordon, S. (2019). How the Bullying Tactics of Politicians Use Affect Kids. Available from https://www.verywellfamily.com/5-bullying-tactics-politicians-use-and-how-it-impacts-kids4080749)

Lakoff, R. (2017). The hollow man. Donald Trump, populism and post-truth politics. Journal of Language and Politics, 16(4), 595-606.

Mey, Jacob. (2001). Pragmatics: An Introduction. Oxford: Blackwell.

Nithyanand, B., Schaffner, B. and Gill, P. (2017). Online Political Discourse in the Trump Era.

Oade, R. (2009). Managing Workplace Bullying. London: Palgrave.

Olweus, D. (1993). Bullying at School. Oxford: Blackwell.

Smith, P., \& Sharp, S. (1994). School Bullying. London: Routledge.

Swearer, S., \& Hymel, S. (2015). Understanding the Psychology of Bullying. American Psychologist, 70(4), 344-353. 
Van Eemeren, F., \& Houtlosser, P. (2002). Strategic Maneuvering: Maintaining a Delicate Balance. In Van Eemeren, F. and Houtlosser, P. (Eds.) Dialectic and Rhetoric: The Warp and Woof of Argumentative Analysis. Dordrecht: Springer.

York, C. (2013). Cultivating Political Incivility: Cable News, Network News, and Public Perceptions. Electronic News, 7(3), 107-125.

\section{AUTHOR BIO DATA}

Prof. Dr. Fareed H. Alhindawi is a professor of linguistics in the College of Education for Islamic University/Najaf/Iraq at English department. He majors in applied pragmatics. He published more than 61 research papers and authored, coauthored, and edited more than 12 books in different fields of linguistics.

Lecturer Dr. Mariam D. Saffah holds an M.A. in Pragmatics from Babylon University, and a Ph.D. in English Language and Linguistics from Babylon University. She is also interested in Pragmatics, Discourse analysis, and stylistics. She published 2 books and 9 research papers.

Lect. Dr. Akram Nadhim Raheem has a Ph.D in English language and linguistics from the University of Babylon. He is currently the head of the department of English at the College of Education Islamic University in an Najaf/Iraq since 2018. 